American Journal of Applied Sciences 7 (12): 1579-1586, 2010

ISSN 1546-9239

(C) 2010 Science Publications

\title{
A Review: Mesoporous Santa Barbara Amorphous-15, Types, Synthesis and Its Applications towards Biorefinery Production
}

\author{
${ }^{1}$ Norhasyimi Rahmat, ${ }^{2}$ Ahmad Zuhairi Abdullah, ${ }^{2}$ Abdul Rahman Mohamed \\ ${ }^{1}$ Faculty of Chemical Engineering, University Technology MARA, \\ 40300 Shah Alam, Selangor, Malaysia \\ ${ }^{2}$ School of Chemical Engineering, USM Engineering Campus, \\ 14300 Seberang Prai Selatan, Pulau Pinang, Malaysia
}

\begin{abstract}
Problem statement: Santa Barbara Amorphous (SBA-15) is significant mesoporous silica with exclusive and important properties of highly ordered mesopores, hydrothermally stable and thick wall, profusely large surface area and huge pore volume which render it as promising catalyst for wide applications. However, the purely siliceous SBA-15 which lacks of acidity characteristic hinders its ideal capabilities as catalyst. Moreover, functionalization and modification of SBA-15 could enhance and optimize its catalytic activity. Conclusion/Recommendations: Thus, in this review, the various types and different synthesis of modifying SBA-15 are discussed in detail towards its application in biorefinery production. The catalytic activities in various operating conditions and reactions are also reviewed for future reference and scope of studies.
\end{abstract}

Key words: Mesoporous materials, biorefinery production, Santa Barbara amorphous, Tetramethyl Orthosilicate (TMOS), catalytic activity, mesoporous structure

\section{INTRODUCTION}

Mesoporous material, as defined by IUPAC nomenclature, is material with pore of free diameters in the range of 2-50 $\mathrm{nm}$ (McCusker et al., 2003). Generally, mesoporous materials is defined with the term of host, pores and chemical composition of its host and guests (Liebau, 2003). Mesoporous materials is more preferred for its highly ordered mesostructure, apart from high surface area, which allows diffusion and adsorption of larger molecules for wide applications than that of microstructure which only limits to separation and fine chemical catalysis (Fedeyko et al., 2006). Moreover, microporous material has selective thermal stability based on size and shape of cage or channel within lattice of selected organic moieties during synthesis, which restricts its potentiality to limited applications (Morey et al., 1998). Mesoporous materials are widely applied in catalysis (Abdalla et al., 2009), drug control delivery (Pasqua et al., 2009), biosensors (Xu et al., 2009b), biofuel (Ooi and Bhatia, 2007), sorption (Chang et al., 2008) and membrane separation (Zornoza et al., 2009). Typical compounds of mesoporous material include silica (Xia and Mokaya, 2003), alumina (Xu et al., 2009a), carbon (Chen et al., 2009)and transition metal oxides (Rao and Antonelli, 2009).

Silica is widely employed as main building block of mesoporous materials because it is inexpensive, thermally stable, chemically inert, harmless (Nandiyanto et al., 2009) and abundantly available in the Earth's crust (Draggan, 2008). Unlike zeolitic materials which are silica self-assembles reliance upon heating, mesoporous silica is formed in the presence of selfassociating molecules such as cationic surfactant for MCM-41 synthesis and block copolymers for synthesis of SBA-15 (Liebau, 2003). Figure 1 shows typical synthesis of mesoporous silica MCM-41.

Mesoporous silica was first discovered in 1990 by researchers in Japan (Yanagisawa et al., 1990) and later was produced in Mobil Corporation Laboratories (Chen et al., 2009) and named as M41S. MCM-41, MCM-48 and MCM-50 are among the widely known mesoporous silica in M41S family (Vartuli et al., 2008) which have different methods of synthesis and applications based on instability and limitation of mesoporous structure (Tatsumi et al., 1999, Zhang et al., 2007).

Corresponding Author: Norhasyimi Rahmat, Faculty of Chemical Engineering, University Technology MARA, 40300 Shah Alam, Selangor, Malaysia 
Am. J. Applied Sci., 7 (12): 1579-1586, 2010

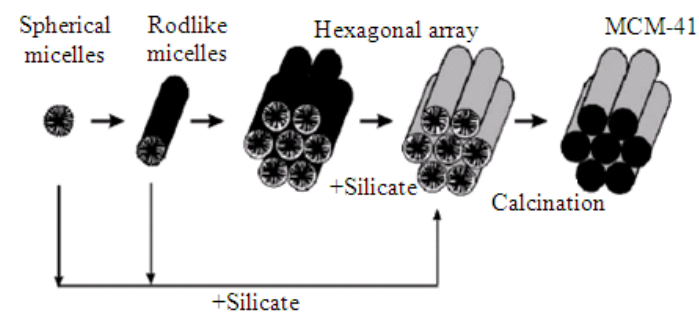

Fig. 1: Liquid crystal templating mechanism of formation of the mesoporous silica material MCM-41(Brady et al., 2008)

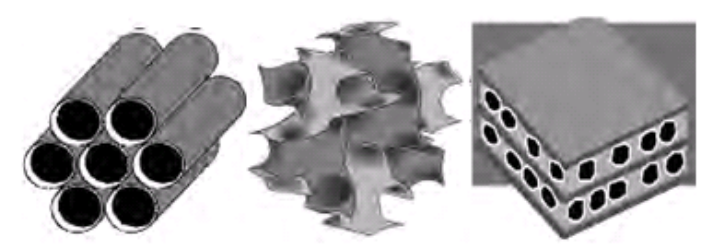

Fig. 2: The M41S family of materials including MCM41, MCM-48 and MCM-50 (Vartuli et al., 2008)

These mesoporous silica are highly ordered, large specific surface area, hexagonal array and uniform mesoporous channel (Chen et al., 2004, Tatsumi et al., 1999). Especially for MCM-41 and MCM-48, the pore size can be controlled and widely used as adsorbent, catalyst and support (Tatsumi et al., 1999). MCM-41 is in hexagonal packed rod-shaped micelle structure, whereas MCM-48 is in cubic and MCM-50 is in lamellar form (Vartuli et al., 2008) which is depicted in Fig. 2. Later in 1995, the research focus was concentrated on mesoporous molecular sieves like HMS (Tanev et al., 1995) and MSU (Bagshaw et al., 1995). In 1998, a prominent research which produces hexagonal array of pores namely as Santa Barbara Amorphous no 15 (SBA-15) with larger pore size from 4.6-30 nm was a research gambit in mesoporous material development (Zhao et al., 1998b). Not only because of its larger pores, but also thermal, mechanical and chemical resistance properties that makes it a preferable choice to other types of catalysts.

Purely siliceous SBA-15: Typical synthesis of SBA-15 requires triblock copolymer, typically non-ionic triblock copolymer (Zhao et al., 1998b) as structure directing agent and Tetramethyl Orthosilicate (TMOS) (Zhao et al., 2000), Tetraethyl Orthosilicate (TEOS) (Zhao et al., 1998a) or Tetrapropyl Orthosilicate (TPOS) (Zhao et al., 1998b) as silica source.
According to Zhao et al. (2000) the formation of ordered hexagonal SBA-15 with uniform pores up to 30 $\mathrm{nm}$ was synthesized using amphiphilic triblock copolymer in strong acidic media i.e., $\mathrm{pH} \sim 1$. If $\mathrm{pH}$ is more than the isoelectric of silica i.e., at $\mathrm{pH} 2-6$, no precipitation or formation of silica gel would occur. Disordered or amorphous silica would likely to be happened at neutral $\mathrm{pH}$ of 7 (Zhao et al., 1998b). Nevertheless, Cui et al. (2005) have proved to synthesize SBA-15 at $\mathrm{pH}$ 2-5, which is above isoelectric point of silica. They suggested that the prehydrolyzed of TEOS at $\mathrm{pH}<3$ would interact with template agent to form a mesophase under weak acidic condition (Cui et al., 2005).

The most recent study is the synthesis of highly siliceous SBA-15 from low silica inorganic precursor with the presence of impurities of industrial waste product which typically consist of metal oxide containing $42 \mathrm{wt} \% \mathrm{SiO}_{2}$. The method used in this study was claimed to be cost effective for bulk production of mesoporous silica since it used industrial waste as silica precursor and no pre-purification of precursor nor material washing steps were applied (Puputti et al., 2009).

Template removal is one of the crucial aspects in ordered mesoporous silica synthesis in which this procedure could modify the final properties of desired porous structure. The usual method of removing template is calcination. According to Zhao et al. (1998a) the calcination of mesoporous structure SBA-15 at $500^{\circ} \mathrm{C}$ would produce final properties of porous structure with interlattice $\mathrm{d}$ spacing of 74.5-320 angstroms between the (100) planes, pore volume fraction up to 0.85 and silica wall thickness of 31-64 angstroms (Zhao et al., 1998a). In preference to studying the final properties of porous structure after calcination, other researchers focused on the calcination behavior during the process of template removal. Kleitz et al. (2003) studied the in situ XRD pattern, intensities reflections and d spacing values of SBA-15 calcination up to $550^{\circ} \mathrm{C}$ and cooling to room temperature after $5 \mathrm{~h}$ (Kleitz et al., 2003). Besides mesoporosity structure, SBA-15 was found to contain micropores which indicated the hierarchical template of material structure (Schmidt-Winkel et al., 1998). These microporous structures are generally disordered and provide interconnectivity between ordered mesopores (Brady et al., 2008).

Modifying SBA-15: Despite promising properties of SBA-15 in catalysis, biomolecule separation, etc, there is still a need to modify or functionalize SBA-15 i.e., to overcome its limitation of low acidity strength (Yue et al., 2000), enhance and optimize its catalytic activity by supporting (Vizcaíno et al., 2009) or 
immobilizing ( $\mathrm{Li}$ et al., 2009) on other elements or complement other catalyst especially for thermal endurance (Grieken et al., 2005), reusability (Liu et al., 2009) and enzymatic activity (Takimoto et al., 2008). Besides, SBA-15 is one of the best candidates to be modified and functionalized since it has controllable pore size, pore volume and high surface area (Liu et al., 2008). Deposition of titanium in SBA-15 material render superior mechanical and chemical resistance (Liu et al., 2008) while activation SBA-15 with different types of metal would develop and design large pore catalysts which allow high diffusion rates (Busuioc et al., 2006). Recently, the attachment of organic functional group has caught attention for further development in which this could tune the hydrophilic-hydrophobic character of silica surface to give sorbent chemical selectivity for specific molecules or ions (Li et al., 2008).

From available literature articles, modified and functionalized SBA-15 can be categorized into different types:

- Functionalization SBA-15 with sulfonic, aminopropyl, imidazole, triazole group (Grieken et al., 2005, Li et al., 2008)

- Enzyme immobilization onto SBA-15 i.e., Porcine pancreatic Lipase, Cyctochrome-c (Li et al., 2009, Washmon-Kriel et al., 2000)

- Metal supported SBA-15 i.e., Pd-Zn, Co (Eswaramoorthi et al., 2009, Prieto et al., 2009)

- Different types of metal incorporation into SBA-15 framework i.e., Al, Ce, La, Ti, Mg, Ca (Calles et al., 2009, Kim et al., 2004, Vizcaíno et al., 2009, Yue et al., 2000)

\section{Synthesis:}

Methods: Various methods of synthesis have been employed, which includes direct synthesis, post synthetically impregnation and grafting, sol-gel as well as immobilization (Cui et al., 2005, Grieken et al., 2005, Li et al., 2009, Calles et al., 2009, Carrero et al., 2007). Table 1 list down different types of modifying SBA-15 and syntheses. However, only direct synthesis and post grafting method will be discussed in this review.

Direct synthesis: Direct synthesis of modifying SBA15 engaged the co-condensation of silica source i.e. TMOS, TEOS etc. with organotrialkoxysilane with presence of different templating agents. Apart from silane group, this method was then further explored and developed by co-condensing silica source with different groups of metal i.e. transition, alkaline earth, rare earth and poor metals.

Phenyl-functionalized-SBA-15 under acidic conditions was concertedly explored by Du et al. (2006). The phenyl-modified-SBA-15 was prepared using direct synthesis method by co-condensation of different molar ratios of tetraethylorthosilicate (TEOS) and phenyltrimethoxysilane (PTMS). It was worthful to note that even at high molar ratio of TEOS: PTMS, the desirable hexagonal structure, large surface area and pore volume were still preserved besides its thermally stable and highly hydrophobic properties (Du et al., 2006) .

A study of Co-SBA-15 was investigated under different $\mathrm{pH}$ adjustment using sodium hydroxide, in which under optimum $\mathrm{pH}$ of 3 , high surface area and pore volume of Co-SBA-15 were demonstrated (Lou et al., 2008). In other work of transition metal incorporation, the effect high loading zirconium in the direct synthesis of Zr-SBA-15 was probed into its catalyst property as well as catalytic activity. The study reported that high ratio of $\mathrm{Zr} / \mathrm{Si}$ established a high order mesostructure of Zr-SBA-15 and additional sulfation process increased its catalytic activity (Fuxiang et al., 2007).

From the recent studies presented here, they are consistent with the argument reported by Zhao et al. (1998a) that direct synthesis proposes a uniform dispersion of functional groups on material surface and structure which preserve its surface properties (Zhao et al., 1998a).

Post-grafting: Post-grafting was the first method used to modify mesoporous silica materials. Basically, this method involves reaction between organosilane with silanol group using solvent under reflux condition to form covalent attachment of functional groups on surface of material (Chong et al., 2004).

It has been reported that post-grafting method has its downside aspects. Among disadvantages of this method includes the reductions of pore size and pore volume caused by the attachment of functional group on pore surface (Lim et al., 1999), density limitation of reactive silanol group that would limit the loading of functional group on pore surface in which would further cause cross-linking between functional groups and silanol groups on surface (White and Tripp, 2000), difficulty in achieving uniformity of the functional group and tedious process which involves more than one step of preparation (Mercier and Pinnavaia, 1999).

Nevertheless, Ma et al. (2010) has employed postgrafting method in incorporating aluminum into SBA15 to observe the effect towards structural, textural and acidity of the catalyst. They discovered that, in comparison with direct synthesis method, the acidity and catalytic activity of Al-SBA-15 synthesized by post-grafting method has shown to be higher due to 
Am. J. Applied Sci., 7 (12): 1579-1586, 2010

Table 1: Different types and synthesis of modifying SBA-15

\begin{tabular}{|c|c|c|c|}
\hline Modifying SBA-15 & Methods of synth & Properties & Remark \\
\hline $\begin{array}{l}\text { AP-SBA-15 } \\
\text { (aminopropyl-SBA- } \\
\text { 15) (Li et al., 2008) }\end{array}$ & $\begin{array}{l}\text { One-step post } \\
\text { grafting }\end{array}$ & $\begin{array}{l}\mathrm{S}_{\mathrm{BET}} \mathrm{m}^{-2} \mathrm{~g}^{-1}=524 \\
\mathrm{VP} \mathrm{cm} \mathrm{gm}^{-1}=0.60 \\
\mathrm{Dp} \mathrm{nm}=6.5 \\
\mathrm{~d}_{(100)} /=92.8\end{array}$ & $\begin{array}{l}\text { After functionalization, XRD patterns show the hexagonal structure still remains } \\
\text { intact. However, the } \mathrm{d}_{(100)} \text { spacing increased as shown in }(100) \text { shifting reflection } \\
\text { to lower } 2 \text { values. The slight decrease in the reflection peak intensity of the } \\
\text { SBA-15 indicated the grafting happened inside the pore channels. }\end{array}$ \\
\hline $\begin{array}{l}\text { Imi-SBA-15 } \\
\text { (Imidazole SBA-15) } \\
\text { (Li et al., 2008) }\end{array}$ & $\begin{array}{l}\text { Two-step post } \\
\text { grafting }\end{array}$ & $\begin{array}{l}\mathrm{S}_{\mathrm{BET}} \mathrm{m}^{-2} \mathrm{~g}^{-1}=362 \\
\mathrm{VP} \mathrm{cm}^{-3} \mathrm{~g}^{-1}=0.57 \\
\mathrm{Dp} \mathrm{nm}=5.6 \\
\mathrm{~d}_{(100)} /=87.3\end{array}$ & \\
\hline $\begin{array}{l}\text { Tri-SBA-15 } \\
\text { (Triazole SBA-15) } \\
\text { (Li } \text { et al., 2008) }\end{array}$ & $\begin{array}{l}\text { Two-step post } \\
\text { grafting }\end{array}$ & $\begin{array}{l}\mathrm{S}_{\mathrm{BET}} \mathrm{m}^{-2} \mathrm{~g}^{-1}=435 \\
\mathrm{VP} \mathrm{cm}^{-3} \mathrm{~g}^{-1}=0.65 \\
\mathrm{Dp} / \mathrm{nm}^{-1}=5.8 \\
\mathrm{~d}_{(100)} /=90.1\end{array}$ & \\
\hline $\begin{array}{l}\text { Al-SBA-15 } \\
\text { (Yue } \text { et al., 2000) }\end{array}$ & Direct synthesis & $\begin{array}{l}\mathrm{S}_{\mathrm{BET}} \mathrm{m}^{-2} \mathrm{~g}^{-1}=1004 \\
\mathrm{VP} \mathrm{cm} \mathrm{g}^{-1}=1.53 \\
\mathrm{Dp} \mathrm{nm}^{-1}=7.4 \\
\mathrm{~d}_{(100)} /=108\end{array}$ & $\begin{array}{l}\text { After various treatment i.e. acidic, basic, neutral and vapor medium, it could be concluded } \\
\text { that Al-SBA-15 is more stable than pure SBA- } 15 \text { in which the pore size, } \mathrm{d}_{(100)} \text { spacing, wall } \\
\text { thickness still remain the same. However, specific surface area and pore volume decrease } \\
\text { in basic medium treatment which indicated the disappearance of microporous phase. }\end{array}$ \\
\hline $\begin{array}{l}\text { Organically modified } \\
\text { Ti -SBA-15 } \\
\text { (Iglesias et al., 2008) }\end{array}$ & Direct synthesis & $\begin{array}{l}\mathrm{S}_{\mathrm{BET}} \mathrm{m}^{-2} \mathrm{~g}^{-1}=1004 \\
\mathrm{VP} \mathrm{cm} \mathrm{g}^{-1}=1.53 \\
\mathrm{Dp} \mathrm{nm}=7.4 \\
\mathrm{~d}_{(100)} /=108\end{array}$ & $\begin{array}{l}\text { Organic modifications of Ti-SBA-15 give high dispersion of metal species and } \\
\text { enhance the hydrophobic behavior. However, it displays poor structured mesophase. } \\
\text { Catalytic activity in epoxidation of 1-octene depends on the length of organic } \\
\text { functionalities in which catalytic activity increases with larger organic functionalities. }\end{array}$ \\
\hline $\begin{array}{l}\text { Ti-SBA-15 } \\
\text { (Busuioce } \text { et al., 2006) }\end{array}$ & Sol-gel method & $\begin{array}{l}\mathrm{S}_{\mathrm{BET}} \mathrm{m}^{-2} \mathrm{~g}^{-1}=534 \\
\mathrm{VP} \mathrm{cm} \mathrm{cm}^{-3} \mathrm{~g}^{-1}=0.63\end{array}$ & $\begin{array}{l}\text { Controlling the amount of titanium, the } \mathrm{pH} \text {, temperature at different stages of } \\
\text { deposition, the characteristics, sorption capacity and catalytic activity can be tuned. }\end{array}$ \\
\hline $\begin{array}{l}\text { 20\%Ti-SBA-15 } \\
\text { (Kim } \text { et al., 2004) }\end{array}$ & Post-grafting & $\begin{array}{l}\mathrm{S}_{\text {ВJH }} \mathrm{m}^{-2} \mathrm{~g}^{-1}=566.4 \\
\mathrm{VP} \mathrm{cm} \mathrm{g}^{-3}=0.85 \\
\mathrm{Dp} \mathrm{nm} \mathrm{g}^{-1}=6.07\end{array}$ & $\begin{array}{l}\text { Higher incorporation of titanium would decrease the specific surface area and pore } \\
\text { volume. However, the catalytic activity increase with the increment of titanium } \\
\text { loading but } \mathrm{H}_{2} \mathrm{O}_{2} \text { selectivity decreased. }\end{array}$ \\
\hline $\begin{array}{l}\text { Co-SBA-15 } \\
\text { (Can et al., 2006) }\end{array}$ & Direct synthesis & $\begin{array}{l}\mathrm{S}_{\mathrm{BET}} \mathrm{m}^{-2} \mathrm{~g}^{-1}=747.5 \\
\mathrm{VP} \mathrm{cm}-\mathrm{g}^{-1}=0.70 \\
\mathrm{Dp} \mathrm{nm} \mathrm{nm}^{-1}=4.68\end{array}$ & $\begin{array}{l}\text { Surface area of SBA- } 15 \text { decrease with the addition of } 40 \mathrm{wt} \% \text { Co. High loading of } \\
\text { Co to SBA- } 15 \text { as metal oxides lead to disappearance of long range order SBA- } 15 \\
\text { which indicates chemical reaction between host SBA-15 and guest metal oxides. }\end{array}$ \\
\hline $\begin{array}{l}\mathrm{Pb}-\mathrm{SBA}-15 \\
\text { (Can } \text { et al., 2006) }\end{array}$ & Direct synthesis & $\begin{array}{l}\mathrm{S}_{\mathrm{BET}} \mathrm{m}^{-2} \mathrm{~g}^{-1}=648.9 \\
\mathrm{VP} \mathrm{cm} \mathrm{g}^{-1}=0.72 \\
\mathrm{Dp} \mathrm{nm} \mathrm{g}^{-1}=4.43\end{array}$ & $\begin{array}{l}\text { No XRD peak characteristic observed for } 5,10,15 \mathrm{wt} \% \mathrm{~Pb} \text { loading suggest } \mathrm{Pb} \text { is finely } \\
\text { dispersed on the surface of the sample or incorporated in the pore wall. XRD peak for } 20 \mathrm{wt} \% \\
\mathrm{~Pb} \text { into SBA-15 indicated the presence of crystallites of metal oxide on the surface. }\end{array}$ \\
\hline
\end{tabular}

Table 2: Application of SBA-15 in biorefinery production

\begin{tabular}{|c|c|c|c|c|}
\hline SBA-15 types & Application & Reaction condition & Conversion & Yield/selectivity \\
\hline $\begin{array}{l}\text { Cu-Ni/SBA-15 } \\
\text { supported catalysts } \\
\text { (Carrero } \text { et al., 2007) }\end{array}$ & $\begin{array}{l}\text { Production of } \\
\text { hydrogen from } \\
\text { bioethanol }\end{array}$ & $\begin{array}{l}\text { Effect of reaction temperature } \\
\text { was studied ranging from } \\
400-650^{\circ} \mathrm{C}\end{array}$ & $\begin{array}{l}\text { At } 600^{\circ} \mathrm{C} \text {, conversion of } \\
\text { ethanol } \sim 100 \mathrm{~mol} \% \text {, } \\
\text { water } 38.6 \mathrm{~mol} \%\end{array}$ & $\begin{array}{l}\text { At } 600^{\circ} \mathrm{C} \text {, hydrogen } \\
\text { selectivity } 85.3 \mathrm{~mol} \%\end{array}$ \\
\hline $\begin{array}{l}\text { SBA-15 } \\
\text { (Badamali et al., 2008) }\end{array}$ & $\begin{array}{l}\text { Production of } \\
\text { acetovanillone } \\
\text { from monomer } \\
\text { lignin, apocynol }\end{array}$ & $\begin{array}{l}\text { Effect of reaction temperature in } \\
\text { microwave reactor from 5-30 min }\end{array}$ & $\begin{array}{l}\text { Double the amount of } \\
\text { catalyst, substrate could } \\
\text { achieve highest } 47.8 \%\end{array}$ & $\begin{array}{l}\text { Double the amounts of } \\
\text { catalyst, however, decrease } \\
\text { the product selectivity }\end{array}$ \\
\hline $\begin{array}{l}\text { RuB/Sn-SBA-15 } \\
\text { (Luo et al., 2007) }\end{array}$ & $\begin{array}{l}\text { Production of } 1,2- \\
\text { propanediol from } \\
\text { hydrogenation of } \\
\text { ethyl lactate }\end{array}$ & $\begin{array}{l}\text { Temperature at } 149.85^{\circ} \mathrm{C}, \\
\mathrm{H}_{2} \text { pressure at } 5.5 \mathrm{MPa}, \\
\text { reaction time up to } 10 \mathrm{~h}\end{array}$ & $\begin{array}{l}\text { Increasing the Sn doping } \\
\text { amount, increase the } \\
\text { substrate conversion to } \\
68.4 \%\end{array}$ & $\begin{array}{l}\text { Increasing the Sn doping } \\
\text { amount, increase the } \\
\text { product selectivity to } \\
98.9 \%\end{array}$ \\
\hline $\begin{array}{l}\text { Al-SBA-15 } \\
\text { (Ooi and Bhatia, 2007) }\end{array}$ & $\begin{array}{l}\text { Production of } \\
\text { gasoline from } \\
\text { waste used palm oil }\end{array}$ & $\begin{array}{l}\text { Reaction temperature at } \\
449.85^{\circ} \mathrm{C} \text {, feed rate of } \\
\text { waste used palm oil } 2.5 \mathrm{~h}^{-1} \\
\text { at atmospheric pressure }\end{array}$ & $\begin{array}{l}\text { Substrate conversion of } 70- \\
80 \% \text { with post-synthesis } \\
\text { catalyst preparation }\end{array}$ & $\begin{array}{l}\text { Achieve higher yield } \sim 40 \% \\
\text { with post-synthesis catalyst } \\
\text { preparation }\end{array}$ \\
\hline $\begin{array}{l}\text { 1.Cu-Ni/Mg- SBA-15 } \\
\text { 2.Cu-Ni/Ca- SBA-15 } \\
\text { (Vizcaino et al., 2009) }\end{array}$ & $\begin{array}{l}\text { Production of } \\
\text { hydrogen from } \\
\text { steam reforming } \\
\text { ethanol }\end{array}$ & $\begin{array}{l}\text { Reaction temperature at } \\
600{ }^{\circ} \mathrm{C} \\
\text { Reaction time for } 3 \mathrm{~h}\end{array}$ & $\begin{array}{l}\text { Ethanol conversion is as } \\
\text { high as } 100 \%\end{array}$ & $\begin{array}{l}\mathrm{H}_{2} \text { selectivity as high as } 83 \% \\
\text { with } \mathrm{Cu}-\mathrm{Ni} / \mathrm{Mg}-\mathrm{SBA}-15 \\
\mathrm{H}_{2} \text { selectivity as high as } 85 \% \\
\text { with } \mathrm{Cu}-\mathrm{Ni} / \mathrm{Ca}-\mathrm{SBA}-15\end{array}$ \\
\hline $\begin{array}{l}\text { K-SBA-15 } \\
\text { (Abdullah } \text { et al., 2009) }\end{array}$ & $\begin{array}{l}\text { Production of } \\
\text { biodiesel from } \\
\text { palm oil } \\
\text { transesterification }\end{array}$ & $\begin{array}{l}\text { Optimum reaction temperature } \\
\text { at } 70^{\circ} \mathrm{C} \text {, reaction time of } 5 \mathrm{~h} \text {, } \\
3.91 \mathrm{wt} \% \text { catalyst, } 11.6 \mathrm{~mol} \mathrm{~mol}{ }^{-1} \\
\text { methanol: Oil }\end{array}$ & $\begin{array}{l}87 \% \text { conversion at } \\
\text { optimum reaction } \\
\text { condition }\end{array}$ & $\begin{array}{l}\text { Biodiesel yield } 93 \% \text { at } \\
\text { optimum reaction condition }\end{array}$ \\
\hline $\begin{array}{l}\text { Ti-Ru-SBA-15 } \\
\text { (Liu et al., 2009) }\end{array}$ & $\begin{array}{l}\text { Production of } \\
\text { alcohol from } \\
\text { allylation- } \\
\text { isomerization of } \\
\text { a.1-phenyl-3-buten- } \\
\text { 1-ol b. benzaldehyde }\end{array}$ & $\begin{array}{l}\text { Reaction temperature } 100^{\circ} \mathrm{C} \text {, } \\
\text { reaction time } 10 \mathrm{~min}\end{array}$ & $\begin{array}{l}\text { Conversion of 1-phenyl-3 } \\
\text {-buten-1-ol } 96.3 \% \\
\text { Conversion of benzaldehyde } \\
98.8 \%\end{array}$ & $\begin{array}{l}\text { Selectivity of 4-phenyl-but- } \\
\text { 3-en-2-ol 97.4\% from 1- } \\
\text { phenyl-3-buten-1-ol } \\
\text { Selectivity of 4-phenyl } \\
\text {-but-3-en-2-ol 95.5\% } \\
\text { from bezaldehyde }\end{array}$ \\
\hline
\end{tabular}


Am. J. Applied Sci., 7 (12): 1579-1586, 2010

Table 2: continuous

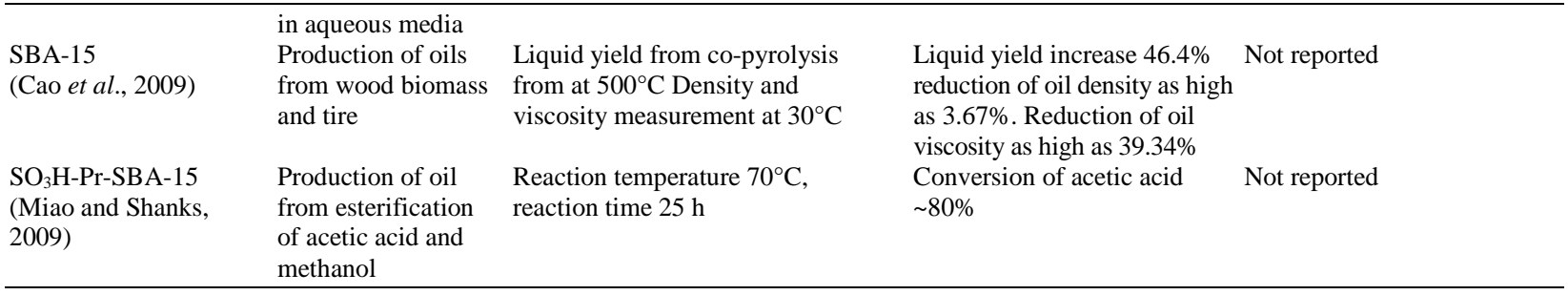

formation of Lewis and Brönsted acid sites (Ma et al., 2010). In previous work by Zeng et al. (2005) the activity of Al-SBA-15 was proved to be affected by hydrolysis ratio and aluminum concentration which could be correlated to various ratio of $\mathrm{Si} / \mathrm{Al}$ (Zeng et al., 2005). This was substantiated by research work of the post-grafting in the synthesis of Al-SBA-15 with various ratio of $\mathrm{Si} / \mathrm{Al}$ which could affect the catalytic activity and stability of the catalyst as well as exhibited better conversion and selectivity (Wu et al., 2006).

The effect on structure and psychochemical properties: Particular interest in synthesizing SBA-15 is also focused on the effect of structure, physical and psychochemical properties of SBA-15.

The initiative to improve the adsorption characteristics of hexagonal has been successfully shown by Colilla et al. (2007) by enlarging the surface area of hexagonally ordered SBA-15 (Colilla et al., 2007). The addition of weak acid $\mathrm{H}_{3} \mathrm{PO}_{4}$ together with strong acid hydrochloric in varied composition contributed to the increment of surface area, mesopores and micropore volume of SBA-15, which markedly characterized by $\mathrm{N}_{2}$ adsorption, Brunauer-EmmettTeller and Small Angle X-ray Diffraction.

The immobilization of Porcine pancreatic lipase on rod-like SBA-15 was investigated to have technical understanding on its adsorption and catalytic activity (Li et al., 2009). The concerted investigations of the effect of $\mathrm{pH}$ medium and thermal stability were studied to find the optimum conditions of this biocatalyst activity. It comes to comprehension that the immobilized Porcine pancreatic lipase on rod-like SBA-15 has maximum activity in $\mathrm{pH}$ medium of 8 , but decreases at the $\mathrm{pH}$ medium of 9 . This could be suggested by the shifting of protons partitioning between bulk phase and enzyme microenvironment in optimum medium of $\mathrm{pH}$ value dependent on the immobilization method, the structure and the charge of the mesoporous carrier.

Incorporation of titanium into SBA-15 with different methods of synthesis, different solvents application and varied amount of titanium deposited have lead to another new research finding of mesoporous material. Das et al.(2010) has successfully synthesized highly ordered 2-D hexagonal titanium incorporated into SBA-15 using non-ionic surfactant pluronic and co-solvent cyclohexane with small amount of titanium deposited (Das et al., 2010). This direct synthesis method has exhibited significant increment surface area of $924 \mathrm{~m}^{2} \mathrm{~g}^{-1}$, compare to that of pure SBA-15 with $611 \mathrm{~m}^{2} \mathrm{~g}^{-1}$. However, $\mathrm{t}$ his is in contrast to the findings from Kim et al. (2004) who found that the post-synthesis of Ti-SBA-15 has lead to the decrease in surface area compared to pure SBA-15 (Kim et al., 2004).

Application in Biorefinery: SBA-15 has been reported to be used widely in biofuel and value-added chemical feedstock from biomass. In the investigations of oil characteristics produced from biomass and tire, SBA-15 has shown to highly reduce the oil density by $3.67 \%$ and oil viscosity by $39.4 \%$, significantly better than that of MCM-41 and HZSM-5 (Cao et al., 2009). A study involved different methods of deposition of $\mathrm{Al}$ into SBA-15 framework by direct synthesis and post synthesis in the production of biofuel from waste-used palm oil indicated comparable catalytic behavior, but regenerated post-synthesis Al-SBA-15 catalyst gave better catalytic activity and fuel yield due to better thermal stability (Ooi and Bhatia, 2007). Other study which also investigated different methods of $\mathrm{Cu}-\mathrm{Ni}$ supported on SBA-15 reported that the catalyst prepared by incipient wetness impregnation showed better selectivity and conversion than that of direct synthesis method in the production of hydrogen from steam reforming bioethanol (Carrero et al., 2007).

Table 2 summarizes some of the applications and catalytic activity of SBA-15 in biorefinery production.

\section{CONCLUSION}

The significant properties of SBA-15 and its modification are remarkably relevant towards the application of biorefinery production. It is important to design modifying SBA-15 with different organic, 
silane, silanol, sulfonic and metal functional groups by improving its structural, textural and psychochemical properties for better shape selectivity and catalytic activity with different means of syntheses and methods. The remarkable research works presented in this review would definitely assist future research work development of mesoporous SBA-15 as novel catalyst in biorefinery application.

\section{REFERENCE}

Abdalla, Z.E.A., B. Li and A. Tufail, 2009. Direct synthesis of mesoporous $\left(\mathrm{C}_{19} \mathrm{H}_{42} \mathrm{~N}\right)_{4} \mathrm{H}_{3}\left(\mathrm{PW}_{11} \mathrm{O}_{39}\right) / \mathrm{SiO}_{2}$ and its catalytic performance in oxidative desulfurization. Colloids Surfaces A: Physicochem. Engineer. Aspects, 341: 86-92. DOI: 10.1016/j.colsurfa.2009.03.042

Bagshaw, S.A. and E. Prouzet, 1995. Templating of mesoporous molecular sieves by nonionic polyethylene oxide surfactants. Science, 269: 1242.

Brady, R., B. Woonton, M.L. Gee and A.J. O'Connor 2008. Hierarchical mesoporous silica materials for separation of functional food ingredients: A review. Innovative Food Sci. Emerg. Technolog., 9: 243-248.

Busuioc, A.M., V. Meynen, E. Beyers, M. Mertens and P. Cool et al., 2006. Structural features and photocatalytic behaviour of titania deposited within the pores of SBA-15. Applied Catalysis A: General, 312: 153-164. DOI: 10.1016/j.apcata.2006.06.043

Calles, J.A., A. Carrero and A.J. Vizcaíno, 2009. Ce and $\mathrm{La}$ modification of mesoporous $\mathrm{Cu}-\mathrm{Ni} / \mathrm{SBA}-15$ catalysts for hydrogen production through ethanol steam reforming. Microporous Mesoporous Mat., 119: 200-207. DOI: 10.1016/j.micromeso.2008.10.028

Cao, Q., L. Jin, W. Bao and Y. Lv, 2009. Investigations into the characteristics of oils produced from copyrolysis of biomass and tire. Fuel Process. Technol., $\quad 90: \quad 337-342 . \quad$ DOI: 10.1016/j.fuproc.2008.10.005

Carrero, A., J.A. Calles and A.J. Vizcaíno, 2007. Hydrogen production by ethanol steam reforming over $\mathrm{Cu}-\mathrm{Ni} / \mathrm{SBA}-15$ supported catalysts prepared by direct synthesis and impregnation. Applied Catalysis A: General, 327: 82-94. DOI: 10.1016/j.apcata.2007.04.030

Chang, C.Y., L.K. Chau, W.P. Hu, C.Y. Wang and J.H. Liao, 2008. Nickel hexacyanoferrate multilayers on functionalized mesoporous silica supports for selective sorption and sensing of cesium. Microporous Mesoporous Mat., 109: 505-512. DOI: 10.1016/j.micromeso.2007.05.057
Chen, J., N. Xia, T. Zhou, S. Tan and F. Jiang et al., 2009. Mesoporous carbon spheres: synthesis, characterization and supercapacitance. Int. J. Electrochem. Sci., 4: 1063-1073. http://www.electrochemsci.org/papers/vol4/408106 3.pdf

Chen, Y., J. Lu, B. Han, M. Li and J. Xiu et al., 2004. Direct synthesis, characterization and catalytic activity of titanium-substituted SBA-15 mesoporous molecular sieves. Applied Catalysis A: General, 273: 185-191. DOI: 10.1021/cm011686c

Chong, A.S.M., X.S. Zhao, A.T. Kustedjo and S.Z. Qiao, 2004. Functionalization of large-pore mesoporous silicas with organosilanes by direct synthesis. Microporous Mesoporous Mat., 72: 33-42. DOI: 10.1016/j.micromeso.2004.04.015

Colilla, M., F. Balas, M. Manzano and M. Vallet-Regí, 2007. Novel method to enlarge the surface area of SBA-15. Chem. Mat., 19: 3099-3101. DOI: $10.1021 / \mathrm{cm} 071032 \mathrm{p}$

Cui, X. et al., 2005. Nonionic triblock copolymer synthesis of SBA-15 above the isoelectric point of silica ( $\mathrm{pH}=2-5)$. Mat. Lett., 59: 2257-2261.

Das, S.K., M.K. Bhunia and A. Bhaumik, 2010. Highly ordered Ti-SBA-15: Efficient $\mathrm{H} 2$ adsorbent and photocatalyst for eco-toxic dye degradation. J. Solid State Chem., 183: 1326-1333. DOI: 10.1016/j.jssc.2010.04.015

Draggan, $\quad$ S., $2008 . \quad$ Silicon. http://www.eoearth.org/article/Silicon.

Du, Y., Y. Sun, Y. Di, L. Zhao and S. Liu et al., 2006. Ordered mesoporous sulfated silica-zirconia materials with high zirconium contents in the structure. J. Porous Mat., 13: 163-171. DOI: 10.1007/s10934-006-7026-5

Eswaramoorthi, I. and A.K. Dalai, 2009. A comparative study on the performance of mesoporous SBA-15 supported Pd-Zn catalysts in partial oxidation and steam reforming of methanol for hydrogen production. Int. J. Hydrogen Energy, 34: 25802590.

Fedeyko, J.M., D.G. Vlachos and R.F. Lobo, 2006. Understanding the differences between microporous and mesoporous synthesis through the phase behavior of silica. Microporous Mesoporous Mat., $\quad 90: \quad 102-111 . \quad$ DOI: 10.1016/j.micromeso.2005.10.048

Fuxiang, L., Y. Feng, L. Yongli, L. Ruifeng and L. Ruifeng, 2007. Direct synthesis of Zr-SBA-15 mesoporous molecular sieves with high zirconium loading: Characterization and catalytic performance after sulfated. Microporous Mesoporous Mat., 101: 250-255. DOI: 10.1016/j.micromeso.2006.12.018 
Grieken, R.V., J.A. Melero and G. Morales, 2005. Fries rearrangement of phenyl acetate over sulfonic modified mesostructured SBA-15 materials. Applied Catalysis A: General, 289: 143-152. DOI: 10.1016/j.apcata.2005.04.059

Kim, M.J., S.H. Chang, J.S. Choi and W.S. Ahn, 2004. Physicochemical properties of Ti-grafted SBA-15. Reaction Kinetics Catalysis Lett., 82: 27-32. DOI: 10.1023/B:REAC.0000028801.47618.01

Kleitz, F. W. Schmidt and F. Schüth, 2003. Calcination behavior of different surfactant-templated mesostructured silica materials. Microporous Mesoporous Mat., 65: 1-29.

Li, J., L. Wang, T. Qi, Y. Zhou and C. Liu, 2008. Different N-containing functional groups modified mesoporous adsorbents for $\mathrm{Cr}(\mathrm{VI})$ sequestration: Synthesis, characterization and comparison. Microporous Mesoporous Mat., 110: 442-450. DOI: 10.1016/j.micromeso.2007.06.033

Li, Y., G. Zhou, C. Li, D. Qin and W. Qiao et al., 2009. Adsorption and catalytic activity of Porcine pancreatic lipase on rod-like SBA-15 mesoporous material. Colloids Surfaces A: Physicochem. Engineer. Aspects, 341: 79-85. DOI: 10.1016/j.colsurfa.2009.03.041

Liebau, F., 2003. Ordered microporous and mesoporous materials with inorganic hosts: definitions of terms, formula notation and systematic classification. Microporous Mesoporous Mat., 58: 15-72.

Lim, M.H. and A. Stein, 1999. Comparative studies of grafting and direct syntheses of inorganic-organic hybrid mesoporous materials. Chem. Mat., 11: 3285-3295.

Liu, G., Y. Sun, J. Wang, C. Sun and F. Zhang et al., 2009. Microwave assisted tandem allylationisomerization reaction catalyzed by a mesostructured bifunctional catalyst in aqueous media. Green Chem., 11: 1477-1481.

Liu, H., H. Wang, J. Shen, Y. Sun and Z. Liu, 2008. Promotion effect of cerium and lanthanum oxides on Ni/SBA-15 catalyst for ammonia decomposition. Catalysis Today, 131: 44-449. DOI: 10.1016/j.cattod.2007.10.048

Lou, Z., R. Wang, H. Sun, H. Sun and Y. Yang, 2008. Direct synthesis of highly ordered Co-SBA-15 mesoporous materials by the pH-adjusting approach. Microporous Mesoporous Mat., 110: 347-354. DOI: 10.1016/j.micromeso.2007.06.020

Ma, J., L.S. Qiang, J.F. Wang, X.B. Tang and D.Y. Tang, 2010. Effect of different synthesis methods on the structural and catalytic performance of SBA-15 modified by aluminum. DOI: 10.1007/s10934-010-9416-y
McCusker, L.B., F. Liebau and G. Engelhardt, 2003. Nomenclature of structural and compositional characteristics of ordered microporous and mesoporous materials with inorganic hosts: (IUPAC recommendations 2001). Microporous Mesoporous Mat, $\quad$ 58: 3-13. http://www.iupac.org/publications/pac/pdf/2001/pd f/7302x0381.pdf

Mercier, L. and T. J. Pinnavaia, 1999. Direct synthesis of hybrid organic-inorganic nanoporous silica by a neutral amine assembly route: Structure-function control by stoichiometric incorporation of organosiloxane molecules. Chem. Mat., 12: 188-196.

Morey, M.S., A. Davidson and G.D. Stucky, 1998. Silica-based, cubic mesostructures: synthesis, characterization and relevance for catalysis. J. Porous Mat., 5: 195-204. DOI: 10.1023/A:1009626103498

Nandiyanto, A.B.D., S.G. Kim, F. Iskandar and K. Okuyama, 2009. Synthesis of spherical mesoporous silica nanoparticles with nanometer-size controllable pores and outer diameters. Microporous Mesoporous Mat., 120: 447-453. DOI: 10.1016/j.micromeso.2008.12.019

Ooi, Y.S. and S. Bhatia, 2007. Aluminum-containing SBA-15 as cracking catalyst for the production of biofuel from waste used palm oil. Microporous Mesoporous Mat., 102: 310-317.

Pasqua, L., S. Cundari, C. Ceresa and G. Cavaletti, 2009. Recent development, applications and perspectives of mesoporous silica particles in medicine and biotechnology. Current Med. Chem., 16: 3054-3063. http://www.ncbi.nlm.nih.gov/pubmed/19689282

Prieto, G., A. Martínez, R. Murciano and M.A. Arribas, 2009. Cobalt supported on morphologically tailored SBA-15 mesostructures: The impact of pore length on metal dispersion and catalytic activity in the Fischer-Tropsch synthesis. Applied Catalysis A: General, 367: 146-156. DOI: 10.1016/j.apcata.2009.08.003

Puputti, J., H. Jin, J. Rosenholm, H. Jiang and M. Lindén, 2009. The use of an impure inorganic precursor for the synthesis of highly siliceous mesoporous materials under acidic conditions. Microporous Mesoporous Mat., 126: 272-275. DOI: 10.1016/j.micromeso.2009.06.017

Rao, Y. and D.M. Antonelli, 2009. Mesoporous transition metal oxides: characterization and applications in heterogeneous catalysis. J. Mater. Chem., 19: 1937-1944.

Schmidt-Winkel, P., W.W. Lukens, Jr., D. Zhao, P. Yang and B.F. Chmelka et al., 1998. Mesocellular siliceous foams with uniformly sized cells and windows. J. Am. Chem. Soc., 121: 254-255. DOI: $10.1021 / \mathrm{ja} 983218 \mathrm{iz}$ 
Takimoto, A., T. Shiomi, K. Ino, T. Tsunoda and A. Kawai et al., 2008. Encapsulation of cellulase with mesoporous silica (SBA-15). Microporous Mesoporous Mat., 116: 601-606. DOI: 10.1016/j.micromeso.2008.05.046

Tanev, P.T. and T.J. Pinnavaia, 1995. A neural templating route to mesoporous molecular sieves. Science, 267: 865.

Tatsumi, T., K.A. Koyano, Y. Tanaka and S. Nakata, 1999. Mechanical Stability of Mesoporous Materials, MCM-48 and MCM-41. J. Porous Mat., 6: 13-17. DOI: 10.1023/A:1009682915127

Vartuli, J.C., W.J. Roth and T.F. Degnan, 2008. Mesoporous materials (M41S): From discovery to application. In: Dekker Encyclopedia of Nanoscience and Nanotechnology, Schwarz, J.A., C.I. Contescu and K. Putyera (Eds.). Taylor and Francis, New York, pp: 1797-1811.

Vizcaíno, A.J., A. Carrero and J.A. Calles, 2009. Ethanol steam reforming on $\mathrm{Mg}$ - and $\mathrm{Ca}$-modified $\mathrm{Cu}-\mathrm{Ni} / \mathrm{SBA}-15$ catalysts. Catalysis Today, 146: 63-70. DOI: 10.1016/j.cattod.2008.11.020

Washmon-Kriel, L., V.L. Jimenez and K.J. Balkus Jr., 2000. Cytochrome c immobilization into mesoporous molecular sieves. J. Molecular Catalysis B: Enzymatic, 10: 453-469. DOI: 10.1016/S1381-1177(99)00123-X

White, L.D. and C.P. Tripp, 2000. Reaction of (3Aminopropyl)dimethylethoxysilane with amine catalysts on silica surfaces. J. Colloid and Interface Sci., 232: 400-407.

Wu, S., J. Huang, T. Wu, K. Song and H. Wang et al., 2006. Synthesis, characterization and catalytic performance of mesoporous Al-SBA-15 for tertbutylation of phenol. Chinese J. Catalysis, 27: 914. DOI: 10.1016/S1872-2067(06)60004-1

Xia, Y. and R. Mokaya, 2003. A study of the behaviour of mesoporous silicas in $\mathrm{OH} / \mathrm{CTABr} / \mathrm{H}_{2} \mathrm{O}$ systems: phase dependent stabilisation, dissolution or semipseudomorphic transformation. J. Mater. Chem., 13: 3112-3121.

Xu, B., J. Long, H. Tian, Y. Zhu and X. Sun, 2009a. Synthesis and characterization of mesoporous [gamma]-alumina templated by saccharide molecules. Catalysis Today, 147: 46-50. DOI: 10.1016/j.cattod.2009.07.059
Xu, X., P. Lu, Y. Zhou, Z. Zhao and M. Guo, 2009b. Laccase immobilized on methylene blue modified mesoporous silica MCM-41/PVA. Mat. Sci. Engineer., 29: 2160-2164. DOI: 10.1016/j.msec.2009.04.019

Yanagisawa, T., T. Shimizu and K. Kuroda, 1990. The preparation of alkyltriinethylaininonium-kaneinite complexes and their conversion to microporous materials. Bull. Chem. Soc. Jpn., 63: 988-992.

Yue, Y.H., A. Gédéon, J.L. Bonardet, J.B. d'Espinose and N. Melosh et al., 2000. Direct incorporation of $\mathrm{Al}$ in SBA mesoporous materials: characterization, stability and catalytic activity. Stud. Surface Sci. Catalysis, 129: 209-218. DOI: 10.1016/S01672991(00)80216-5

Zeng, S., J. Blanchard, M. Breysse, Y. Shi and X. Shu et al., 2005. Post-synthesis alumination of SBA-15 in aqueous solution: A versatile tool for the preparation of acidic Al-SBA-15 supports. Microporous Mesoporous Mat., 85: 297-304. DOI: 10.1016/j.micromeso.2005.06.031

Zhang, B., X. Tang, Y. Li, Y. Xu and W. Shen, 2007. Hydrogen production from steam reforming of ethanol and glycerol over ceria-supported metal catalysts. Int. J. Hydrog. Energy, 32: 2367-2373. DOI: 10.1016/j.ijhydene.2006.11.003

Zhao, D., J. Feng, Q. Huo, N. Melosh and G.H. Fredrickson, 1998a. Triblock copolymer syntheses of mesoporous silica with periodic 50 to 300 angstrom pores. Science, 279: 548. DOI: 10.1126/science. 279.5350 .548

Zhao, D., Q. Huo, J. Feng, B.F. Chmelka and G.D. Stucky, 1998b. Nonionic triblock and star diblock copolymer and oligomeric surfactant syntheses of highly ordered, hydrothermally stable, mesoporous silica structures. J. Am. Chem. Soc., 120: 6024-6036.

Zhao, D., J. Sun, Q. Li and G.D. Stucky, 2000. Morphological control of highly ordered mesoporous silica SBA-15. Chem. Mat., 12: 275-279.

Zornoza, B., S. Irusta, C. Tellez and J. Coronas, 2009. Mesoporous silica sphere polysulfone mixed matrix membranes for gas separation. Langmuir, 25: 5903-5909. 